\title{
Company's Corporate Legal Capacity: Problems of the Ultra Vires Rule, Modern Shift and Position of Bangladesh
}

\section{Md. Omar Faruque Munshi*}

Supreme Court of Bangladesh, Dhaka-1000, Bangladesh.

*Correspondence:omarfaruque.munshi@gmail.com(Md. Omar Faruque Munshi, Advocate, Supreme Court of Bangladesh, Ex Research Fellow, Institute of Bangladesh Studies (IBS), University of Rajshahi, Bangladesh).

\section{ABSTRACT}

The traditional ultra vires rule has been applied restricting the corporate capacity of an incorporated entity. It being a 'legal person' can function only within the defined objects of its constitution. Long experience of applying this rule shows that, the doctrine served no positive purpose (e.g. limiting the company's transactions to some precise line of the stated objectives in its constitution), rather it produced many unsatisfactory state of affairs and difficulties like operating as fetter on company's new business opportunities, risk of company's transaction being treated as void in court's proceedings interpreting it "outside the company's constitution" and is unenforceable. Thus, the parties in a corporate transaction are always at risk to suffer irremediable loss if at any stage either of the parties renounces the contractual obligation. For the said and many other unsatisfactory results of the traditional ultra vires rule, many developed countries have either completely abolished it from their company law or greatly limited its applications to some statutorily defined cases only. But Bangladesh still retained the century's old outmoded tradition, even though recently the Companies (Amendment) Act 2020 passed. In the array of a vast literature on this particular issue, and a great number of legislative reform proposals in many other countries and instances of their legislative reforms, it is not understandable in the legislative policy of Bangladesh for retaining it. This article analyses the historical factors behind applying this rule, the irrationality of those considerations and its present time irrelevance.

Keywords: Corporate capacity, Ultra vires rule, Corporate entity, and Company law reform.

\section{INTRODUCTION:}

The term ultra vires comes from Latin - ultra means beyond and vires means powers. The phrase ultra vires act of a company is used to describe an act which is beyond the company's corporate legal capacity and thus is illegal and void. The limitation upon corporate capacity of a company classically interpreted deriving from those objects as are stated in the object clause in its constituting documents (made up with two documents-memorandums of association and articles of association). Under the traditional legal requirement, the objects in incorporating a company must be men- tioned in its constitution documents. In law an incurporated company treated as a "legal being", in other words termed as "corporate legal person", a body corporate, created and existed only in contemplation of law. As such its functional capacity is limited in respect to those of defined objectives only as are mentioned in its constituting documents. Any act outside those stated objectives is thus according to classical legal theoretical discourse interpreted as beyond the corporate capacity, i.e. ultra vires, and hence void. In modern world the application of the rule has now been greatly modified, especially upon finding that its 
application served no positive legal purpose except producing adverse impacts on the company's investing opportunity not desirable in the present free economic movement. So long as these rules is retained in company law and continue to apply by the courts, a party to a corporate transaction which is ultra vires, is always at the risk to suffer unwarranted damage in the event other party denies its contractual obligation even though received benefit under it. The point here is that, an ultra vires transaction being void in law no right can stand upon it which the court will enforce. Thus, the party who becomes aggrieved in such transactions by the above stated denial is without any remedy.

\section{Problems of the Application of Ultra Vires Rule}

The classical interpretation and application of the above stated rule created problems both to the compony's business function and persons dealing with it.

Firstly, in conducting the affairs of the company the doctrine proved unsatisfactory because the 'objects clause' operated as a fetter upon it in embarking on any new business transactions. In each and every occasion of corporate transaction, the contracting parties would first need to be assured whether it is within company's corporate capacity looking into the "functional objectives clause" of its constitution. If upon reading the 'objects clause' inference can be drawn on the total lack of capacity on the contemplated transaction, or any doubt arises as to having that capacity, the company would then be required to include such transactional capacity in its constitution by an amendment. The process of bringing such amendment is a difficult one, as it would require taking special resolution passed on three fourth majority votes of shareholders and the approval of the Court. It might be that any new undertaking would thus become frustrated in completing such time-consuming cumbersome amending procedure. To mitigate this problem, the UK Companies Act, 1948 relieved companies to obtain court's approval in altering the objects clause. Such legal reformation removing the cumbersome process of altering the object clause brought in many other countries also illustrated below in this paper. But it is not understandable why the Companies Act, 1994 of Bangladesh still retained it though recently the Companies (Amendment) Act 2020 passed (Section 12 of the Companies Act, 1994).

UniversePG I www.universepg.com
Secondly, each of the functional objectives mentioned in the company's memorandum in its actual field involves one or more ancillary powers to pursue its goal. For example, the statement of the objects in the memorandum of the company included one object as follows - "to manufacture, distribute and trading on cement". Confusion might arise or the room remains open for questioning whether it has the necessary power to enter into contract to import coal under a trading arrangement. The confusion might also arise whether with this statement of functional object the company possessed the power of entering into joint venture production-sharing contract with another cement manufacturing company. Interpreting and construing of such issues often project undesirable legal debates and doubts in corporate transactions and in many cases the dispute roll into the court's cases. The instances of it are abundant impeding company's business and investment opportunities time to time.

Thirdly, in corporate transactions both the parties (i.e. the company and the outsider third party) are at risk of being unjustly prejudiced by the operation of ultra vires rule. Gower and Davies' Principles of Company Law illustrated this as follows:

Too often companies launched into new lines of business, without realizing that changes in their objects clauses were needed and, as a result, wholly innocent people who had granted them credit might find themselves without a remedy. So might the company on contracts which it had entered into, for, as a crowning absurdity, it seems that, such contract being void, not only could the incapable company not be sued but it could not sue the other party (Davies, Paul, 2003).

\section{Barriers in protecting third party aggrieved by the ultra vires corporate transactions under exis- ting legal treatments}

The following discussion shows how the protection to third party in ultra vires transactions of companies might also fail even if argued these three judicial principles - (i) principle of vicarious liability; (ii) Truquand principle on company vs outsider transactions; and (iii) 'good faith' or 'bona fide' principle. To extend legal protection to the unwary third party's right in ultra vires corporate transactions, many lawyers generally resort to agency principle to enforce 
the company's liability. They argue that, the functions of the company are carried out through its directors, managers and other officials. It gives rise to principalagent relationship between the company and its directors or officials in transactions done in the name of companies. Under the agency principle, a company is vicariously liable for transactions done by its managers, directors, officials etc. as long as the agent is working within his authorized power. But such an argument can be discarded by the courts in ultra vires transactions of company being it in excess of company's capacity, there could be no authorization of power from the company to its directors, managers, officials etc. An act which the company lacks in the capacity of performing, its agents cannot assume the authority to it (Davies, ibid. at p. 142). As such a third party aggrieved by such transaction cannot enforce it against the company on the plea of principal-agent relationship.

The second is the principle established in the Royal British Bank vs. Turquand (Royal British Bank vs. Turquand, 1856). The principle provided that, in a transaction with the company, the outsider third party may presume the regularity of corporate transactions. In other words, the outsider may presume that the company has complied with all the internal management procedures in transacting it as required by its constitution (i.e. the "articles of association"). Under the Turquand principle, an outsider third party in transaction with the company cannot be denied of his remedy to enforce corporate obligation on the ground that the director did not comply the internal management procedures required under the company's constitution to enter it. But it is to be remembered here that the Turquand principle is not applicable to the ultra vires acts of the company (but to the act or transaction only, which is done within the corporate capacity under its constitution, but done violating some internal management procedures required under the "articles of association").

The third is the "bona fide or good faith principle" on the protection of outsider third party entering into transactions with a company. According to this principle, where such a party dealt in good faith in entering into a transaction with a company, he cannot be adversely affected by any restrictive provisions put into its UniversePG I www.universepg.com constitution. But to avail the protection of this bona fide principle, the core thing is the 'appreciation of good faith' in the dealing in question. Things which were in the mind of the transacting party are not easy to determine. Court generally applies some objective tests for it. Certainly in an ultra vires corporate transaction, the decision of the court would be relied holding that, the limitation on the company's capacity being put into the company's constitution filed with the Office of the Registrar of Companies, is opened for public inspection, hence it operates as constructive notice to the party entering into a deal. Thus the bona fide or good faith rule would not also apply to ultra vires transactions of the company's constitution.

\section{Ultra vires Doctrine in Company Law: Historic Tradition and Modern Reformations}

\subsection{Historic Root of Legal Mistreatment of Busi-} ness Corporations - An examination to the historic fact of the origin of the "corporate legal personhood" concept, its application to the business companies with which now we are concerned, and problems ensued in the subsequent theoretical legal discourses and the continuance of fault-line would better explain the rationality and irrationality of ultra vires doctrine to modern companies. But given the very limited scope of such historic analysis in this article, a brief outline of it only given below -

(a) The "company law" or the "law of business corporation" from its historical origin to modern perspectives of companies faced two challenges, first, is the challenge of framing the effective legal scheme addressing the commercial context of companies formed by a group of private individuals, the basic legal assumptions or theories being borrowed from a different field of their applications - the State created entities serving the public function which were wholly unconnected with the commercial reality of our companies. The theories that underlie at the foundation of company law were originally developed in a different branch of law - the law governing the State created "entities" to discharge its public function, hence, they were known as "public corporations". These State created bodies had their peculiar "entity conception" in law and legal "functional capacity". Its basic "legal assumptions" used to be discussed in the branch of law known as the "law of corporate body" or "law of cor- 
poration". These entities were created under the specific parliamentary Act or Crown's Charter. The "Parliamentary Act" or "Crown's Charter" then defined the independent functional domain of the entity created under it that served as the "legal soul" of such "artificial entity" and could function only within the defiled limit under it. The conferment of "corporate person hood" under the law to these "artificial entities" endowed some legal rights, liabilities and functional capacity that were discussed in the branch of law mentioned above. The "company law" or the "law of business corporation" to which we are now concerned is a subsequent origin developed with legal theories by importation from it. This historic root of the "corporate entity" concept and its "corporate capacity" have been discussed and analysed in a number of renowned research papers and courts' cases (in reference number 7).

(b) Having imported the concepts from that heterogeneous field, subsequent adaptations have misstated in several respects; particularly concepts interpreting the company's "legal personhood", its capacity as a "corporate person" and "defining relationships" of shareholders to it.

(c) Thereafter, with the outbreak of new problems in the ever-increasing complexity of modern companies, those concepts went on further adaptation process in which the concepts behind the legal framework once again misstated for failing to treat the problems free from the historical legacy of thinking.

\subsection{Tradition of the common law courts of applying} and interpreting the doctrine - The courts in different countries of common law heritage in ruling on the ultra vires transactions of companies' frequently referred to the House of Lords' decision given in the Ashbury Railway Carriage and Iron Company v. Riche (1875) case as the authoritative comment on the matter. The case decided that an ultra vires transaction is void $a b$ initio, and since the company lacks the capacity to enter into such contract it cannot be validated even by unanimous ratification of shareholders.

\subsection{The emergence of the practice among company lawyers stating long list of functional objects in the company's constitution document - As the time rolled onwards from the said historic origin of the use of "corporate personhood" concept, the lawyers in an UniversePG I www.universepg.com}

effort to bypass the ultra vires rule effect started drafting the company's memorandum enumerating long list of objectives when registering a company. Such a practice led to the enumeration of company's main objects and the incidental objects or powers at the same place. Thus, the difficulty arose on drawing the differentiating line between the independent objects and the powers ancillary to them. Moreover, practice developed in the legal engineering of lawyers too often add an evasive phrase at the end of the objects clause stating in the like nature that- "all those mentioned objectives would be construed as the independent objects, and that no restrictive meaning be assigned to them in interpreting the capacity of the company to lessen their scope whatsoever". This was done partly with the aim of evading the consequences of the ultra vires rule on company's transactions, and with the fear of the time-consuming cumbersome procedure of amending the "object clause of the memorandum" by taking approval on petition to the court. The practice of drafting the whole-embracing objects clause in the memorandum was then further multiplied with the lawyers starting to add an omnibus statement at the end of the 'objects clause' as follows:

The company will have power to carry on any other trade or business whatsoever which can in the opinion of the board of directors, be advantageously be carried on by the company in connection with or as ancillary to any of the above businesses or general business of the of company.

As a result, the ultra vires rule on "corporate transactions" now have the least value than what it was originally intended except to remain as a nuisance to the corporate business and a trap to the unwary third party entering into transactions with the company. From the said experience of the ultra vires rule, countries of the world now increasingly started revising its application. Many countries of the world including the UK, USA, Hong Kong, Switzerland and most of the countries of the EU have now either abolished or greatly revised the ultra vires rule in their company laws. The position of Bangladesh remained unchanged and no initiative in such a modern trend yet found towards reforming the ultra vires rule. The rule derives its full effect under provision of sections 6,7 , and 8 read with section 12 of the Companies Act, 1994. 
4.4. Impact of European Union in UK towards reforming the ultra vires Rule - European Union law played an important role in initiating the legislative change in member countries. With the aim of establishing the integrated market within the member countries, the European Union issued the Company Law Directives providing guidance on required legislative framework for the member countries. These directives have had considerable influence over the UK Companies Acts of 1980, 1981, 1989, and 2006.

The earlier Companies Act 1985 of UK in section 2 though retained the older position of enumerating the objects in the companies' memorandum, latter reenacted to conform to the EC First Directive on the Company law (The EC First Directive 68/151/EEC of 9 March 1968). Substantial effect to the provision of section 9(1) of the European Communities Act, 1972 was given effect by the UK's Companies Act, 1985 in its section 35 providing firstly, that in the corporate transaction entered into by the decision of directors, the outsider third person acting in good faith, can assume it within the capacity of the company and such transaction will be free from any limitations on the directors' powers placed in the memorandum and articles, and secondly, it relieved the other party of any obligation to inquire about matters of any limitation on the company's capacity contained in those document (Gower's Principles of Company Law, p. 209).

The 1985's reform was a partial implementation of the EC First Directive and in the line of the recommendations of the Jenkins Committee report, (1962). The limited protection which such reformation extended only in respect of third parties acted bona fide in entering into transaction with the company. Such a limited protection under the 1985's Company Act was widely criticized for its failing fully to implement the EC Directive and left much to be decided on policy ground. It did not contemplate the protection of the company against the effect of ultra vires rule to its transactions where the other party though received benefit of the transaction latter declined to perform its obligation. The directive does not specifically deal with this point, as Gower explained that, presumably because prior to the entry of the common law country it did not occur to anyone party to the Directive that any legal system could be so asinine as to allow a third UniversePG I www.universepg.com party to invoke ultra vires against the company (and the company could not) (Ibid. at p. 208). Considering further reform necessity, in December 1985, the UK Department of Trade and Industry (DTI), appointed Professor Dan Prentice to examine the legal and commercial implications of abolishing the ultra vires rule. His report which he titled as the refined version of his recommendations was delivered in 1986. It was circulated by the DTI under the title Reform of the Ultra Vires Rule: A Consultative Document, which in the words of Gower was a more complicated but less far reaching, followed by the enactment the Companies Act 1989 (Ibid).

The report of Professor Prentice originally recommended that companies should be afforded the capacity to do any act whatsoever and the option of whether or not stating their objects in their memoranda. But the Prentice Commission Report was given a partial and modified effect under the Companies Act 1989 of UK.

\subsection{Present Position under the UK Companies Act,} 2006 reforming the ultra vires rule - The UK Company's Act 2006 is shown a shift to the traditional "functional object clause" statement in the memorandum. Section 31 of the Act 2006 relieved the companies from stating in their memoranda and thus can have the unfettered functional capacity unless they choose to specifically state its functional objectives in their "articles of association". Thus, the reform effectted that, except the company deliberately has chosen to restrict its functional objects, the ultra vires rule on corporate functional capacity will have no application. Under this reform, the memorandum got the stable document not required to be altered along the new lines of company's business ventures. Thus, the Act 2006 brought a revolutionary change in UK liberalizing the companies' capacity as like as a natural person unless they chose to limit the corporate capacity in their constitution. Even if a company chose to mention its functional objects in the constitution, it will operate for its internal management purpose only not affecting the obligations under the transaction entered by it. The statement of objects in its constitution will have the effect as like the "corporate affairs management contract" between the directors and shareholders of the companies. Outsiders will be unaffected by it. 
Company will be capable to embark on any new line of activity subject only to amend its constitution by the simple procedure of taking shareholders' general meeting resolution (in the case where the objects are mentioned in the articles) and giving notice of it to the registrar.

\subsection{The USA context of reforming the ultra vires} rule - In the USA Federation, States by their individual laws empower business corporations engaging in any lawful business, unless the incorporators choose by its "articles of association" limit company's function to some specified activities only by express terms. The incorporators can exclude objects clause altogether from their constitution when applying to incorporate their company. In America, the Model Business Corporation Act, 2002 (MBCA) provides that, "every corporation incorporated under this Act has the purpose of engaging in any lawful business unless a more limited purpose is set forth in the articles of incorporation" The MBCA provides that "the validity of corporate action may not be challenged on the ground that the corporation lacks or lacked power to act" (Section 3.01 of the MBCA 2002). The MBCA also provides for some "general powers" which each corporation deemed to have irrespective of their mentioning or not in the incorporation documents. Thus, the MBCA by making redundant the mention of such powers in the company's constitution reduced the unnecessary prolixity in the statement of objects and powers. In USA, the ultra vires rule of corporate function now applies only to non-profit corporations or State-created corporate bodies established for some specific public purposes defined in their constitutions, e.g., universities or charities. The MBCA allowed invoking ultra vires rule in challenging the acts of the corporations under three circumstances as follows (Section 3.04 of the MBCA 2002):

(a) Except as provided in subsection (b), the validity of corporate action may not be challenged on the ground that the corporation lacks or lacked power to act.

(b) A corporation's power to act may be challenged:

(1) in a proceeding by a shareholder against the corporation to enjoin the act;

(2) in a proceeding by the corporation, directly, derivatively, or through a receiver, trustee, or other legal representative, against an incumbent or former UniversePG I www.universepg.com director, officer, employee, or agent of the corporation; or

(3) in a proceeding by the Attorney General.

4.7. Reformation of the rule in Hong Kong -The Companies (Amendment) Ordinance 1997 (Ordinance No.3 of 1997) of Hong Kong abolished the ultra vires effect on corporate transactions. Since 1997 the statement of functional objects of companies made optional except for some companies mentioned in section 21 . Such companies are formed for promoting commerce, art, science, religion, charity or any other useful object, and are required to apply their profits, if any, or other income in promoting their objects.

4.8. Reformation of the rule in India - In India the new Companies Act came into being on $29^{\text {th }}$ August, 2013 amending the earlier Companies Act, 1956. Though it did not abolish the traditional ultra vires rule on the corporate transactional capacity, it is notable of the amended Act is that, it made possible the alteration of the 'functional objects clause' by a simpler process of taking special resolution in the general meeting of shareholders and filing it before the Registrar of companies. Under section 13(9) of the present Act, the Registrar shall register the alteration to the statement of company's functional objects and certify the registration within a period of thirty days from the date of filing of the special resolution of the company in support of it. After complying with this simple procedure the amendment of articles shall take effect. The procedure of such alteration in the objects clause of the company's memorandum earlier was subject to some stricter and cumbersome procedure like obtaining the approval of the Company Law Board.

\subsection{The position of Bangladesh in respect of apply-} ing this rule - The Companies Act, 1994 of Bangladesh retained the full effect of the classical ultra vires rule as is explained in the ruling of the case Ashbury Railway Carriage, (1875) mentioned above. The corporate transaction which may be interpreted as outside the stated objects of the company's constitution is void and a nullity. Bangladesh is the direct transplant country of common law of UK. Although much before the enactment of its Companies Act, 1994 (which is made upon the earlier Companies Act, 1913), the reformative initiatives instantiated in UK towards modification of the effect of classical ultra vires rule 
on corporate transaction, and at present in UK this rule retained effect only to some limited extents, no such reformative initiative has ever been taken in Bangladesh in this regard up to now, even if the reforming Act 2020 (Act No. XXIV of 2020) came into being on 26th November 2020.

The Companies Act, 1994 in section 6(a) (iii) provides for the requirement of stating by the companies its functional objects in the memorandum. Besides that, the stricture has been placed upon altering the objects clause of the memorandum by section 10(1) providing that:

A company shall not alter the conditions contained in its memorandum except in the case and the mode and to the extent for which express provision is made in the Act.

Section 12 of the Act specified seven grounds upon which the alteration to the object clause may be sought to the court after taking special resolution for it by the Company in its general meeting. Thus the combined effect of the above stated provisions under sections 6(a) (iii), 10(1) and 12 can be summarized as that after the objects clause has been stated in the company's memorandum (as the law required mentioning), they cannot be altered or amended except the legal procedures for it and to the extent only allowed by the this Act. This position of company law of Bangladesh corresponds to the UK's Companies Act prior to its modification in 1948. Thus, the traditional ultra vires rule with all its impropriety and problems has been full retained by the Companies Act of Bangladesh. Now it is for the policy makers, legislators and all concerned to pay their prompt attention and take effective steps in the worldwide present trends towards reformulating this century's old rule by enacting appropriate legislation for it.

\section{Whether Different Application of this rule is desirable for Statutory Corporations}

The different application of this rule is desirable to the statutory corporations. The reasons are illustrated below. Statutory corporations are those which are created by the statute with some specific duties of public purpose and possess only those powers expressed and implied in the statute (e.g. House Building Finance Corporation, Road Transport Corporation, Shipping
Corporation, Agricultural Development Corporation, City Corporation etc.). It is implicit from their respective statutes that they have been formed to perform only those functions which are specifically conferred upon them, and acts which exceed those powers treated as ultra vires. In this respect the decision in a Canadian Supreme Court case Communities Economic Development Fund v. Canadian Pickles Corp, (1991) is worth referring which held that, as the statutory corporation created for a public purpose it has only those powers which are expressly or impliedly granted to it by statute. Acts which exceed those powers will be ultra vires. The court in deciding the case also took consideration of the Privy Council decision given in Benanza Creek Gold Mining Co. Vs. The King.

\section{CONCLUSION:}

The rule ultra vires transaction of companies is now urgently required greatly revise to modern business companies. Many of the modern countries, for much of the criticisms to this rule as explained above, have now either totally abolished it, or narrowed down its application attaching qualifying languages in their company law statutes. References of such reformation steps in countries are abundant including South Africa, China and in most of the member States of the European Union in this regard. The company law of Bangladesh is inherited from the British company law as the transplant country of common law. Although much before the adoption of the Companies Act, 1994 of Bangladesh, the reform on the ultra vires rule was started in UK, its application is retained with full effect in Bangladesh though not found any positive impact of such retention. To keep pace with the company law modernization all over the world and global business and investment relationship, no least delay is desirable to reform the rule removing all its impropriety and misapplications. One issue in such amending the rule may be raised, whether by abolishing the doctrine the company directors would get the unfettered power to run the company and thereby undermining the present support for the 'increased shareholders control' value perspective. Certainly, the reformation to this rule would not impact so. Shareholders may still choose to restrict the directors' power to some defined objectives of the constitution of the company. But any such restriction would be operative only between the share- 
holders and directors of the company as their internal governance matter.

The guiding issue on liability determination would be that, the transaction is not that it is ultra vires of corporate functional capacity, but that it is in excess of directors' powers as conferred upon them by the shareholders mentioned in its cons-titution. The outsider third party who bona fide in-volved in the transaction with company would not be affected by any such limitation put into the companies' documents. The third party would have the right to recover the amount which the company gained from the transaction in question, and the vise versa for the company also. Provisions may also be made in the Companies Act providing for recovery by the company any damage caused by the unauthorized acts of directors if it can be established that the directors willfully disregarded their powers.

\section{ACKNOWLEDGEMENT:}

Firstly, the acknowledgement is given to those researches which were though not directly connected to this present research topic but because of their analysis of some allied issues (e.g. "theory of corporate entity" and subsets, history of its application in company law and subsequent fault line), have aided the logical presentation of this research. Having the limited scope of this present paper, the individual viewpoints of those scholars could not be accommodated except only mentioning of their brief collective coincidence of findings on these. However, mention is made to some of those researches at end of this paper (in reference number 7). Secondly, in respect of main subject matter at issue of this research paper, acknowledgement is to be given to the authoritative analysis of Paul L Davies, (2003.) in the book Gower and Davies' Principles of Modern Company Law, a renowned book to company lawyers, of which discussions about "ultra vires rule" consulted in aid to support the arguments here with due references. Lastly that, the reformations of statutes in many other countries covering the subject matter of this paper were also worth referencing but only very few of selected countries have been mentioned here though the type of reformations in many other non-mentioned countries have studied for the purpose of this research.

\section{CONFLICTS OF INTEREST:}

The author declares there are no potential conflicts of interest in the present study for publication.

\section{REFERENCES:}

1) Ashbury Railway Carriage and Iron Company v. Riche, (1875). L.R. 7 H.L. 653.

https://thecompany.ninja/ashbury-railway-carriage$\underline{1875 /}$

2) Benanza Creek Gold Mining Co. Vs. The King, (1916), 1 A.C. 566.

https://canliiconnects.org/fr/r\%C3\%A9sum\%C3\% A9/34421

3) Communities Economic Development Fund v. Canadian Pickles Corp, (1991). 3 S.C.R. 388 https://decisions.scc-csc.ca/scc-csc/scc-csc/en/it em/812/index.do

4) Companies Act, 1994 of Bangladesh (Section 12)., as amended $25^{\text {th }}$ February, 2020 (Act No. XXIV of 2020)

5) Davies, Paul L., (2003). Principles of Modern Company Law (Sweet and Maxwell, London: $7^{\text {th }}$ ed.), atp.142.

6) Davies, ibid. p.133.

7) For the historic analysis of the "corporate entity and its functional capacity" theory may be referred to following and many others -

a) Blackstone, William. Commentaries on the Laws of England, $1^{\text {st }}$ ed. (Oxford, Clarendon Press, 1765).

https://en.wikipedia.org/wiki/Commentaries o n the Laws_of England

b) Blumberg, Philip I., (1990). "The Corporate Entity in Era of Multinational Corporation." Delaw. J. of Corp. Law 15, no. 2: 283-375. https://core.ac.uk/download/pdf/302392009.pdf

c) Blumberg, Philip I., (2001). "Account-ability of Multinational Corporations: The Barriers Presented by Concepts of the Corporate Juridical Entity." Hasting Inter-national and Comparative Law Review. 24: 297 - 320. https://opencommons.uconn.edu/law_papers/1 37/

d) Carter, James Treat, (1919). "The Nature of the Corporation as a Legal Entity." PhD diss., Johns Hopkins University. 
e) Clark, Francis William, (1866). A Treatise on the Law of Partnership and Joint Stock Companies, According to the Law of Scotland, vol. 1 (London: Stevens and Sons, 1866), 34.

https://books.google.tg/books?id=cGcIAAAA MAAJ

f) Krannich , Jess M., (2005). "The Corporate 'Person': A New Analytical Approach to a flawed Method of Constitutional Interpretation," Loyola University Chicago Law J. 37 (2005): 67.

https://lawecommons.luc.edu/cgi/viewcontent .cgi? article $=1200 \&$ context $=$ luclj

g) Kyd, Steward, (1793). A Treatise in the Law of Corporations, London, J. Butterworth Fleet Street, 1793.

h) Morawetz Victor, (1886). A Treatise on the Law of Private Corporations (Boston: Little, Brown, and Company, 1886). https://lawcat.berkeley.edu/record/322521

i) Spelling, T., (1892). Carl. A Treatise on the Law of Private Corporations (New York: L. K. Strouse \& Co., 1892).

j) Sutton's Hosp., (1612). 10 Coke 23a, 30b32b, 77 Eng. Rep. 960, 970-73. https://en.wikipedia.org/wiki/Case_of_Sutton $\% 27 \mathrm{~s}$ Hospital

k) Trustees of Dartmouth College v. Woodward, 17 U.S. 518 (1819).

8) Gower's Principles of Company Law, (1954). p. 209.

https://digitalcommons.law.yale.edu/cgi/viewconten t.cgi article $=8406 \&$ context $=y l j$

9) Ibid.

10) Ibid. at p. 208. Also see accompanying footnotes therein with his comments.
11) In UK the rigor of 'objects clause' was relaxed firstly by the Companies Act, 1948. Now under the UK's present Companies Act, 2006 the ultra vires rule retains the least effect so far it provides that, unless a company's articles specifically restrict the objects of the company, its objects are unrestricted (section 31(1)), and that the validity of a company's act is not to be questioned on the ground of lack of capacity because of anything contained in a company's constitution (section 39). The Act also removed the constructive notice doctrine which in the past could be invoked in ultra vires cases (section 40).

12) Royal British Bank vs. Turquand, (1856). 6 E. \& B. 327, Exch.Ch; (1843 - 60) All E.R. Rep. 435. https://www.coursehero.com/file/61629881/CaseBrief-Royal-British-Bank-v-Turquand-1856-6-EB327pdf/

13) Section 3.01 of the MBCA, (2002). Cited supra.

14) Section 3.01(a) of the Model Business Corporation Act, (2002). USA, here in after referred as 'the MBCA 2002'.

15) Section 3.04 of the MBCA, (2002). Cited supra. https://en.wikipedia.org/wiki/Model_Business_Corp oration Act

16) Section 12 of the Companies Act, (1994). Bangladesh also remained the same even if the Companies (Amendment) Act, 2000 of $25^{\text {th }}$ February, 2020.

17) The EC First Directive 68/151/EEC of 9 March 1968. https://lexparency.org/eu/31968L0151/

18) The exception is the companies that are Charities will need to restrict their objects under charities legislation and some other community interest companies may also choose to do so.

Citation: Munshi MOF. (2021). Company's corporate legal capacity: problems of the ultra vires rule, modern shift and position of Bangladesh, Asian J. Soc. Sci. Leg. Stud., 3(4), 119-127. https://doi.org/10.34104/ajssls.021.01190127 @) $\underset{\mathrm{BY}}{\mathrm{Br}}$ 